Supporting information for:

\title{
Mechanism of Alkyne Insertion of a Cationic Zirconocene Aryl Complex
}

\author{
Orson L. Sydora, Stefan M. Kilyanek and Richard F. Jordan* \\ Department of Chemistry, The University of Chicago, 5735 South Ellis Avenue, Chicago, \\ Illinois, 60637 \\ E-mail: rfjordan@uchicago.edu
}

\section{Contents}

I. Experimental Details

II. Kinetic Scheme

III. Kinetic analysis of the reaction of
Page

$\mathrm{S} 2$

S4

S6

IV. Computational Details

S11

V. Metrical parameters of the calculated structures of $\mathbf{C}, \mathbf{T S}$ and $\mathbf{D}$ 


\section{Experimental Details}

[C $\left.\mathbf{p}_{2} \mathbf{Z r}\left(\mathbf{2}-\mathrm{Me}-\mathbf{4}-\mathbf{F}-\mathbf{C}_{6} \mathbf{H}_{3}\right)\right]\left[\mathbf{B}\left(\mathbf{C}_{6} \mathbf{F}_{5}\right)_{4}\right]$ (1). A chlorobenzene solution $(15 \mathrm{~mL})$ of $\mathrm{Cp}_{2} \mathrm{Zr}\left(2-\mathrm{Me}-4-\mathrm{F}-\mathrm{C}_{6} \mathrm{H}_{3}\right)_{2}(150 \mathrm{mg}, 0.341 \mathrm{mmol})$ and $\mathrm{Cp}_{2} \mathrm{ZrMe}_{2}(85.8 \mathrm{mg}, 0.341 \mathrm{mmol})$ was added dropwise to a chlorobenzene solution $(5 \mathrm{~mL})$ of $\left[\mathrm{Ph}_{3} \mathrm{C}\right]\left[\mathrm{B}\left(\mathrm{C}_{6} \mathrm{~F}_{5}\right)_{4}\right](629 \mathrm{mg}$, $0.682 \mathrm{mmol}$ ) in the dark. The mixture was stirred for $1 \mathrm{~h}$ at $23{ }^{\circ} \mathrm{C}$, the chlorobenzene was removed under vacuum, and the resulting orange oil was washed with benzene ( 3 x 10 $\mathrm{mL}$ ) to remove the triphenylethane side product. The orange oil was dried under vacuum yielding $\left[\mathrm{Cp}_{2} \mathrm{Zr}\left(2-\mathrm{Me}-4-\mathrm{F}-\mathrm{C}_{6} \mathrm{H}_{3}\right)\right]\left[\mathrm{B}\left(\mathrm{C}_{6} \mathrm{~F}_{5}\right)_{4}\right] \cdot\left(\mathrm{C}_{6} \mathrm{H}_{6}\right)_{1.8}$ as an orange solid $(0.54 \mathrm{~g}, 34 \%)$.

In $\mathrm{CD}_{2} \mathrm{Cl}_{2}$ (1) forms the solvent adduct A. ${ }^{1} \mathrm{H}$ NMR $\left(\mathrm{CD}_{2} \mathrm{Cl}_{2},-89{ }^{\circ} \mathrm{C}\right): \delta 6.97(\mathrm{~m}, 2 \mathrm{H}, \mathrm{H} 3$ \& H4), 6.31 (s, 10H, Cp), $5.96\left(\mathrm{dd},{ }^{3} J_{\mathrm{HH}}=7.8,{ }^{4} J_{\mathrm{HF}}=4.0,1 \mathrm{H}, \mathrm{H} 6\right), 2.32(\mathrm{~s}, 3 \mathrm{H}, \mathrm{Me})$. ${ }^{13} \mathrm{C}\left\{\right.$ gated- $\left.{ }^{1} \mathrm{H}\right\}$ NMR $\left(\mathrm{CD}_{2} \mathrm{Cl}_{2},-89{ }^{\circ} \mathrm{C}\right): \delta 186.3(\mathrm{~s}, \mathrm{C} 1), 162.5\left(\mathrm{~d},{ }^{1} J_{\mathrm{CF}}=247, \mathrm{C} 4\right), 147.8$ $\left(\mathrm{d},{ }^{3} J_{\mathrm{CF}}=6, \mathrm{C} 2\right), 118.1\left(\mathrm{dd},{ }^{1} J_{\mathrm{CH}}=156,{ }^{2} J_{\mathrm{CF}}=20, \mathrm{C} 3\right), 113.0\left(\mathrm{~d},{ }^{1} J_{\mathrm{CH}}=176, \mathrm{Cp}\right), 112.1$ $\left(\mathrm{dd},{ }^{1} J_{\mathrm{CH}}=162,{ }^{2} J_{\mathrm{CF}}=21, \mathrm{C} 5\right), 97.7\left(\mathrm{dd},{ }^{1} J_{\mathrm{CH}}=129,{ }^{3} J_{\mathrm{CF}}=10, \mathrm{C} 6\right), 23.0\left(\mathrm{q},{ }^{1} J_{\mathrm{CH}}=127\right.$, Me). ${ }^{19} \mathrm{~F}\left\{{ }^{1} \mathrm{H}\right\}\left(\mathrm{CD}_{2} \mathrm{Cl}_{2},-89{ }^{\circ} \mathrm{C}\right): \delta-114.6(\mathrm{~s})$.

Generation of $\left[\mathrm{Cp}_{2} \mathbf{Z r}\left(\mathbf{2}-\mathrm{Me}-4-\mathrm{F}-\mathrm{C}_{6} \mathbf{H}_{3}\right)(2\right.$-butyne $\left.)\right]\left[B\left(\mathbf{C}_{6} \mathbf{F}_{5}\right)_{4}\right]$. (C) An NMR tube was charged with $\left.\mathrm{Cp}_{2} \mathrm{Zr}\left(2-\mathrm{Me}-4-\mathrm{F}-\mathrm{C}_{6} \mathrm{H}_{3}\right)\right]\left[\mathrm{B}\left(\mathrm{C}_{6} \mathrm{~F}_{5}\right)_{4}\right] \cdot\left(\mathrm{C}_{6} \mathrm{H}_{6}\right)_{2}(15.9 \mathrm{mg}, 0.0136$ $\mathrm{mmol})$ and $\mathrm{CD}_{2} \mathrm{Cl}_{2}(0.6 \mathrm{~mL})$ was added by vacuum transfer at $-78{ }^{\circ} \mathrm{C}$. The tube was vigorously agitated, cooled to $-196{ }^{\circ} \mathrm{C}$, and 2-butyne $(0.258 \mathrm{mmol})$ was added by vacuum transfer. The tube was warmed to $-94{ }^{\circ} \mathrm{C}$, vigorously agitated and placed in a pre-cooled NMR probe at $-85{ }^{\circ} \mathrm{C}$. NMR analysis after $5 \mathrm{~min}$ at $-85^{\circ} \mathrm{C}$ showed formation of $\mathrm{Cp}_{2} \mathrm{Zr}(2-$ Me-4-F- $\left.\mathrm{C}_{6} \mathrm{H}_{3}\right)(2-\text { butyne })^{+}(26.4 \%)$ and $\mathrm{Cp}_{2} \mathrm{Zr}\left\{\mathrm{CMe}=\mathrm{CMe}\left(2-\mathrm{Me}-4-\mathrm{F}-\mathrm{C}_{6} \mathrm{H}_{3}\right)\right\}^{+}(31.2 \%)$ and $\mathrm{Cp}_{2} \mathrm{Zr}\left(2-\mathrm{Me}-4-\mathrm{F}-\mathrm{C}_{6} \mathrm{H}_{3}\right)^{+}(42.3 \%)$. This distributions was determined from intensities of the corresponding ortho-Me resonances. ${ }^{1} \mathrm{H}$ NMR data for $\left[\mathrm{Cp}_{2} \mathrm{Zr}\left(2-\mathrm{Me}-4-\mathrm{F}-\mathrm{C}_{6} \mathrm{H}_{3}\right)(2-\right.$ butyne) $]^{+}\left(\mathrm{CD}_{2} \mathrm{Cl}_{2},-90{ }^{\circ} \mathrm{C}\right): \delta 6.95$ (m, $2 \mathrm{H}, \mathrm{H} 3$ and H5), 6.21 (s, $\left.10 \mathrm{H}, \mathrm{Cp}\right), 5.98(\mathrm{~m}, 1 \mathrm{H}$, H6), 2.41 (s, $3 \mathrm{H}, o-\mathrm{Me}), 2.10$ (s, $6 \mathrm{H}$, $\equiv \mathrm{CMe}) .{ }^{13} \mathrm{C}\left\{{ }^{1} \mathrm{H}\right\} \mathrm{NMR}\left(\mathrm{CD}_{2} \mathrm{Cl}_{2},-90{ }^{\circ} \mathrm{C}\right)$ : Key resonances $\delta 112.8(\mathrm{Cp}), 78.6(\equiv C-\mathrm{Me}), 20.9(o-\mathrm{Me}), 10.0(\equiv \mathrm{CMe})$.

Generation of $\left[\mathrm{Cp}_{2} \mathrm{Zr}\left\{\mathrm{CMe}=\mathrm{CMe}\left(2-\mathrm{Me}-4-\mathrm{F}-\mathrm{C}_{6} \mathbf{H}_{3}\right)\right\}\right]\left[\mathrm{B}\left(\mathrm{C}_{6} \mathbf{F}_{5}\right)_{4}\right](\mathrm{D})$. An NMR tube was charged with $\left.\mathrm{Cp}_{2} \mathrm{Zr}\left(2-\mathrm{Me}-4-\mathrm{F}-\mathrm{C}_{6} \mathrm{H}_{3}\right)\right]\left[\mathrm{B}\left(\mathrm{C}_{6} \mathrm{~F}_{5}\right)_{4}\right] \cdot\left(\mathrm{C}_{6} \mathrm{H}_{6}\right)_{2}(21.0 \mathrm{mg}, 0.0180$ $\mathrm{mmol})$ and $\mathrm{CD}_{2} \mathrm{Cl}_{2}(0.6 \mathrm{~mL})$ was added by vacuum transfer at $-78{ }^{\circ} \mathrm{C}$. The tube was vigorously agitated, cooled to $-196{ }^{\circ} \mathrm{C}$, and 2-butyne $(0.0913 \mathrm{mmol})$ was added by vacuum transfer. The tube was warmed to $-78{ }^{\circ} \mathrm{C}$, vigorously agitated and placed in a pre- 
cooled NMR probe at $-70{ }^{\circ} \mathrm{C}$. NMR analysis after $15 \mathrm{~min}$ at $-70{ }^{\circ} \mathrm{C}$ that showed complete conversion to $\left[\mathrm{Cp}_{2} \mathrm{Zr}\left(\mathrm{C}(\mathrm{Me})=\mathrm{C}(\mathrm{Me})\left(2-\mathrm{Me}-4-\mathrm{F}-\mathrm{C}_{6} \mathrm{H}_{3}\right)\right]^{+}\right.$had occurred. ${ }^{1} \mathrm{H} \mathrm{NMR}\left(\mathrm{CD}_{2} \mathrm{Cl}_{2}\right.$, $\left.-70{ }^{\circ} \mathrm{C}\right): \delta 7.80(\mathrm{~m}, 1 \mathrm{H}, \mathrm{Ar}), 7.51(\mathrm{~m}, 1 \mathrm{H}, \mathrm{Ar}), 6.65$ (s, $\left.5 \mathrm{H}, \mathrm{Cp}\right), 6.49$ (m, $\left.1 \mathrm{H}, \mathrm{Ar}\right), 5.90$ (s, $5 \mathrm{H}, \mathrm{Cp}), 2.56$ (s, $3 \mathrm{H}, o-\mathrm{Me}), 1.84(\mathrm{~s}, 3 \mathrm{H},=\mathrm{CMe}), 1.73(\mathrm{~s}, 3 \mathrm{H},=\mathrm{CMe}) .{ }^{13} \mathrm{C}\left\{{ }^{1} \mathrm{H}\right\}$ $\operatorname{NMR}\left(\mathrm{CD}_{2} \mathrm{Cl}_{2},-70{ }^{\circ} \mathrm{C}\right): \delta 194(\mathrm{ZrC}), 165.0\left(\mathrm{~d},{ }^{1} \mathrm{~J}_{\mathrm{CF}}=259, \mathrm{C} 4\right), 137.6,133.3115 .8(\mathrm{Cp})$, $115.4(\mathrm{Cp}), 114.4,113.8,112.5\left({ }^{2} \mathrm{~J}_{\mathrm{CF}}=20, \mathrm{C} 3\right.$ or C5 $), 111.7\left(\mathrm{~d},{ }^{2} \mathrm{~J}_{\mathrm{CF}}=20, \mathrm{C} 3\right.$ or C5), 21.8, 21.1, 18.8. Addition of several drops of $\mathrm{MeOD}$ to a solution of $\mathbf{D}$ produced $\mathrm{MeDC}=\mathrm{C}\left(2-\mathrm{Me}-4-\mathrm{F}-\mathrm{C}_{6} \mathrm{H}_{3}\right) \mathrm{Me}$ in 83\% GC yield; GC-MS: Calcd m/z 165, found 165 . 


\section{Kinetic Scheme}

The following is a description of the standard method of treating reaction a preequilibrium kinetic system. ${ }^{\text {i }}$ The reaction

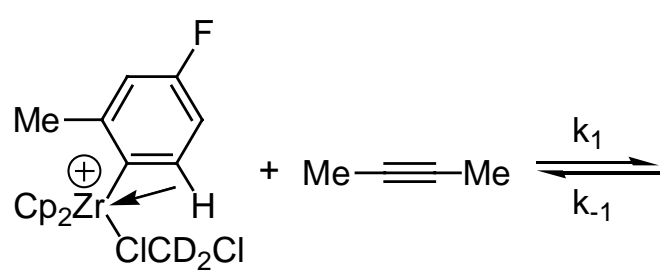

A

B

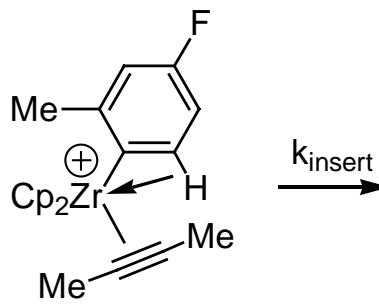

C

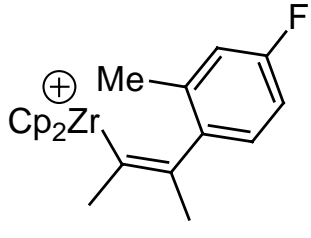

D

consists of a fast equilibrium between $\mathbf{A}$ and $\mathbf{B}$ to form $\mathbf{C}$, which reacts irreversibly to form D. B is present in $>10$-fold excess va. A. The rate law is

$$
\text { rate }=\frac{d[D]}{d t}=k_{\text {ins }}[C]
$$

If we define $[R]$ as the concentration of "remaining reactants",

$$
[R]=[A]+[C]
$$

and the total concentration of $\mathrm{Zr}$ species $\mathrm{T}$ as

$$
T=[A]+[C]+[D]
$$

then

$$
[R]=T-[D] .
$$

The equilibrium constant is defined as

$$
K_{e q}=\frac{[C]}{[A] \cdot[B]}
$$

$$
\frac{1}{K_{e q}}=\frac{[A] \cdot[B]}{[C]}
$$

$$
\frac{1}{K_{e q}[B]}=\frac{[A]}{[C]}
$$

Adding 1 to each side gives 


$$
\frac{1}{K_{e q}[B]}+1=\frac{[A]}{[C]}+\frac{[C]}{[C]}=\frac{[A]+[C]}{[C]}=\frac{[R]}{[C]}
$$

It follows that

$$
[C]=\frac{[R]}{\left(\frac{1}{K_{e q} \cdot[B]}+1\right)}=\frac{K_{e q}[B] \cdot[R]}{K_{e q}[B]+1}=\frac{K_{e q}[B] \cdot(T-[D])}{K_{e q}[B]+1}
$$

therefore

$$
\text { rate }=\frac{d[D]}{d t}=k_{i n s}[C]=\frac{k_{i n s} K_{e q}[B] \cdot(T-[D])}{K_{e q}[B]+1}=k_{o b s}(T-[D])
$$

where

$$
k_{o b s}=\frac{K_{e q}[B] \cdot k_{i n s}}{K_{e q}[B]+1}=\frac{[C] \cdot k_{i n s}}{[A]+[C]}
$$

Or, since

$$
\begin{gathered}
\frac{d[D]}{d t}=\frac{d(T-[R])}{d t}=k_{o b s}[R] \\
-\frac{d[R]}{d t}=k_{o b s}[R]
\end{gathered}
$$

$$
[D]=T-[R]
$$

which corresponds to the first order decay of the total unreacted zirconium containing species $[\mathrm{A}]+[\mathrm{C}]$ or

$$
\ln \left(\frac{R}{R_{0}}\right)=-k_{o b s} \cdot t
$$




\section{Kinetic analysis of the reaction of $\left.\mathrm{Cp}_{2} \mathrm{Zr}\left(2-\mathrm{Me}-4-\mathrm{F}-\mathrm{C}_{6} \mathrm{H}_{3}\right)\right]\left[\mathrm{B}\left(\mathrm{C}_{6} \mathrm{~F}_{5}\right)_{4}\right]$ with 2- butyne.}

Figure $\mathrm{S} 1$ shows a representative ${ }^{1} \mathrm{H}$ NMR spectrum from the beginning of a kinetic run (i.e. immediately following the thermal equilibration period).

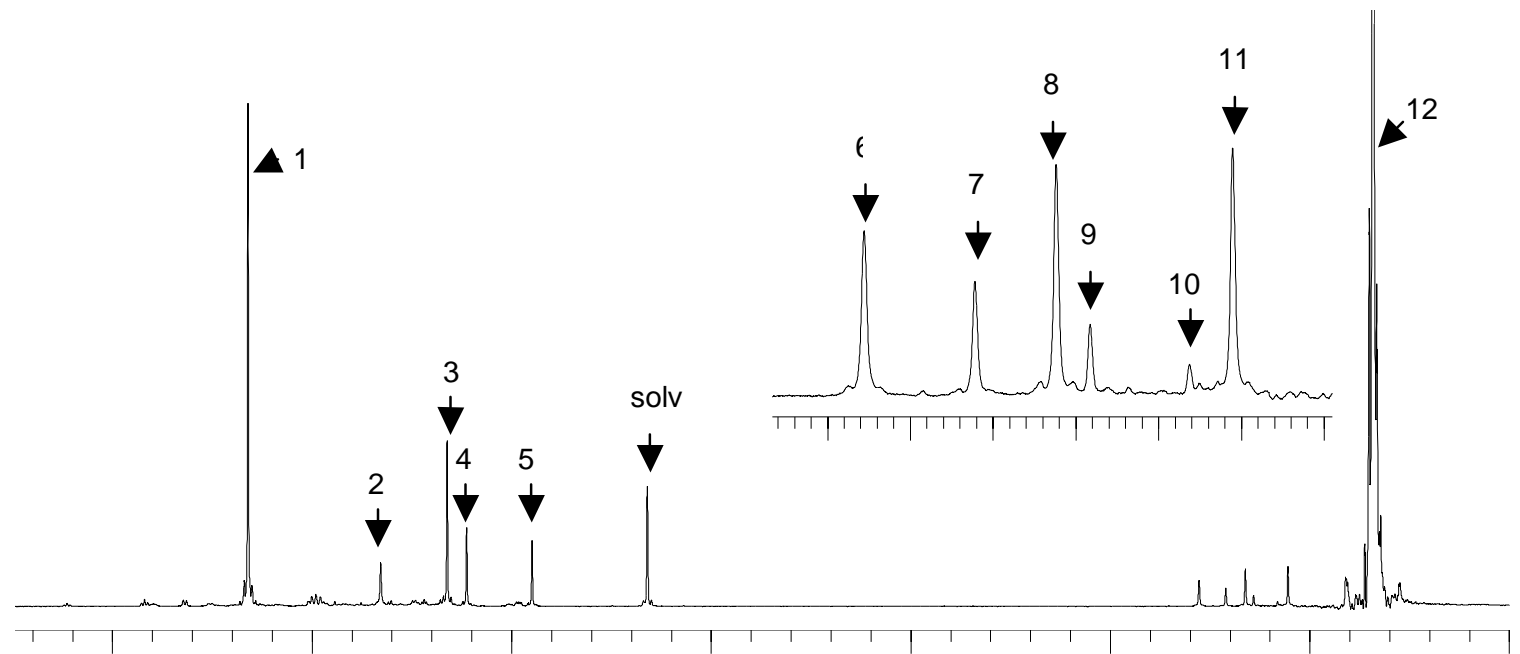

Figure S1. ${ }^{1} \mathrm{H}$ NMR spectrum of the reaction of $\mathbf{A}$ with 2-butyne at $-85^{\circ} \mathrm{C}$. Peak 1: benzene, Peak 2: Cp resonance of $\mathbf{D}$, Peak 3: Cp resonance of $\mathbf{C}$, Peak 4: Cp resonance of A, Peak 5: Cp resonance of $\mathbf{D}$, Peak 6: o-tolyl resonance of $\mathbf{D}$, Peak 7: o-tolyl resonance of $\mathbf{C}$, Peak 8: o-tolyl resonance of A, Peak 9: o-tolyl resonance of 4-F-otoluene (product of C-H activation of 2-butyne ), Peak 10: $\mathrm{Cp}_{2}\left(\mathrm{ZrCMeCMeCH}_{2} \mathrm{CCMe}\right)^{+}$ resonance of C-H activation product, Peak 11: Me groups from coordinated 2-butyne in C, Peak 12: 2-butyne. 
Figure S2 shows a typical series of NMR spectra from a kinetic run (see run 1 below).

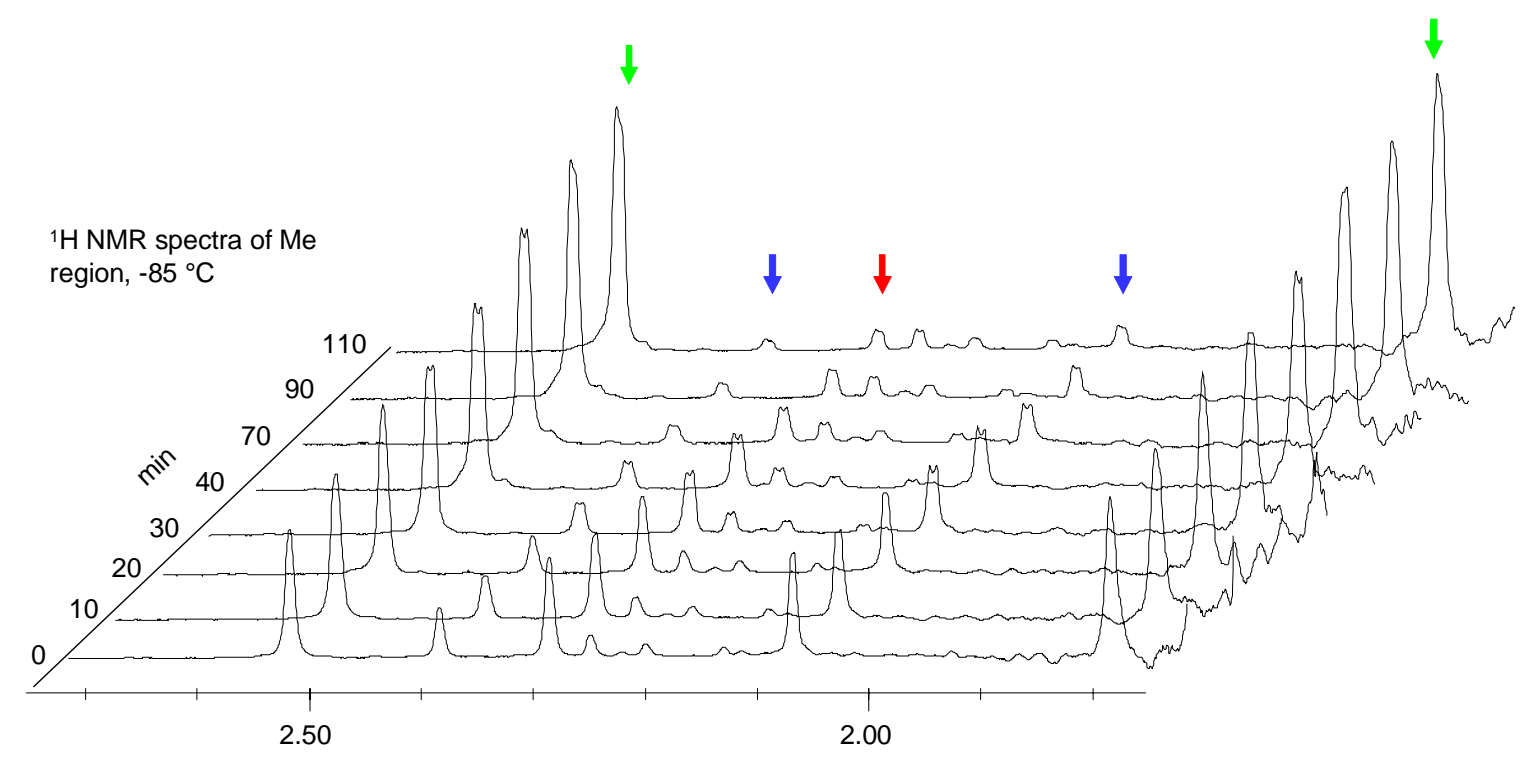

Figure S2. ${ }^{1} \mathrm{H}$ NMR spectra for a typical kinetic run (see run 1 below). The time is the time following completion of the thermal equilibration period. Peaks from left to right: Green: Me peak of D, Blue: Me peak of C, Red: Me peak of A. Blue: 2-butyne from C, Green: overlap of alkenyl Me from $\mathbf{D}$ and with free 2-butyne ${ }^{13} \mathrm{C}$ satellite.

In order to determine the concentration of $\mathrm{Zr}$ species, the total amount of benzene must be known since $\left.\mathrm{Cp}_{2} \mathrm{Zr}\left(2-\mathrm{Me}-4-\mathrm{F}-\mathrm{C}_{6} \mathrm{H}_{3}\right)\right]\left[\mathrm{B}\left(\mathrm{C}_{6} \mathrm{~F}_{5}\right)_{4}\right]$ is added a benzene solvate. The concentration of $\mathbf{A} \cdot$ benzene is known from the mass of $\mathbf{A} \cdot$ benzene added and the volume of the solvent. The concentration of benzene can be determined at each data point or in a separate NMR experiment. There is little difference between the two methods. The average of the concentration of benzene at each point was used in the analysis. Once the concentration of benzene was known, the total concentration of $\mathrm{Zr}$ species was calculated, $[\mathrm{T}]$. The benzene integral was used as an internal standard. The integral regions were set to be identical between all spectra in a kinetic run using XWINNMR. The ratio of the integral of an o-Me peak of a given species to the total integrals of all the o-Me peaks equals the mole fraction of that species; for example the mole fraction of $\mathbf{A}$ equals the ratio of the o-Me integrals $\mathbf{A} /(\mathbf{A}+\mathbf{C}+\mathbf{D})$. The mole fraction was multiplied by $[\mathrm{T}]$ to determine the concentration of each species and the concentration of "remaining reactants" [R] (eq 4 and 12-14). The $k_{\text {obs }}$ was determined from a fit of $\ln \left(\mathrm{R} / \mathrm{R}_{0}\right)$ vs time 
(eq 15, see representative plots in Figures S3 and S4). The time $=0$ is the first point after the thermal equilibration period (10 and 15 min after immersion in the $-85{ }^{\circ} \mathrm{C}$ probe respectively for runs 1 and 2 shown below). $K_{\mathrm{eq}}=[\mathbf{C}][\mathbf{B}]^{-1}[\mathbf{A}]^{-1}$ was determined using $[\mathbf{A}]$ and $[\mathbf{C}]$ determined by the method described above, and $[\mathbf{B}]$ determined from the ratio of the integral of $\mathbf{B} . k_{\text {ins }}$ was determined using eq 11. Uncertainties were estimated using standard differential propagation of error, assuming an uncertainty of $\pm 5 \%$ in the NMR integrals and $\pm 5 \mathrm{~K}$ in the temperature.

Table S1 lists the concentration vs. time data for run 1. Figure S3 is a plot of $\ln \left(\mathrm{R} / \mathrm{R}_{0}\right)$ vs. time for run 1 .

Table S1. Concentration vs. time data for run 1.

\begin{tabular}{ccccc}
\hline Time $(\min )^{a}$ & {$[\mathbf{A}](\mathrm{M})$} & {$[\mathbf{C}](\mathrm{M})$} & {$[\mathrm{D}](\mathrm{M})$} & $\%$ conversion \\
\hline 0 & 0.00691 & 0.00407 & 0.00978 & 47 \\
10 & 0.00634 & 0.00333 & 0.0110 & 53 \\
20 & 0.00560 & 0.00285 & 0.0123 & 59 \\
30 & 0.00489 & 0.00256 & 0.0133 & 64 \\
40 & 0.00435 & 0.00230 & 0.0141 & 67 \\
70 & 0.00268 & 0.00109 & 0.0169 & 81 \\
90 & 0.00229 & 0.00121 & 0.0172 & 83 \\
110 & 0.00176 & 0.000930 & 0.0180 & 87 \\
\hline
\end{tabular}

${ }^{a}$ Time after completion of thermal equilibration period. 


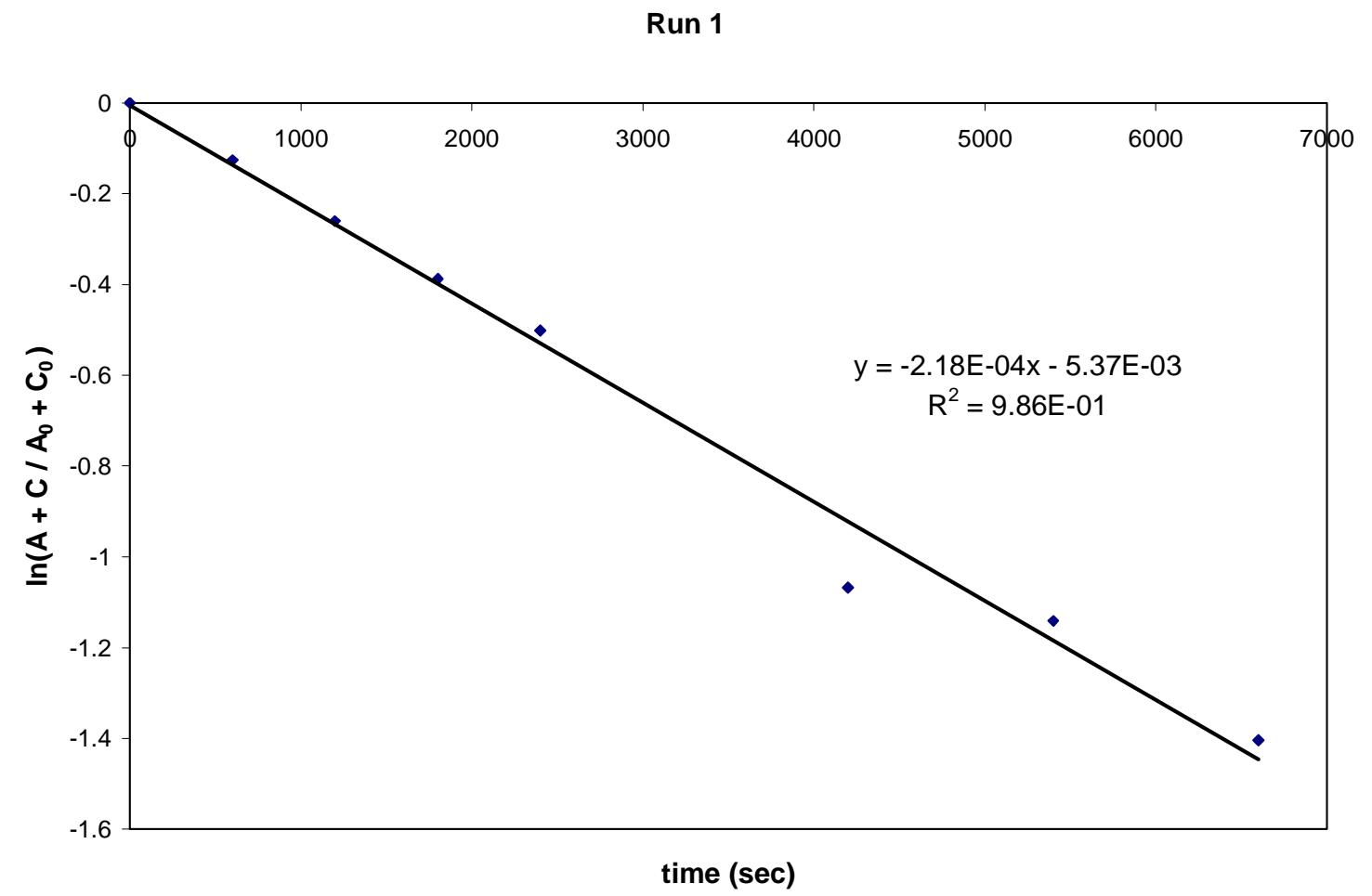

Figure S3. Plot of $\ln \left(\mathrm{R} / \mathrm{R}_{0}\right)$ vs time for run 1 .

Table S2 lists the concentration vs. time data for kinetic run 2. Figure S4 is a plot of $\ln \left(\mathrm{R} / \mathrm{R}_{0}\right)$ vs time

Table S2. Concentration vs. time data for run 2.

\begin{tabular}{ccccc}
\hline time $(\min )^{a}$ & {$[\mathbf{A}] \mathrm{M}$} & {$[\mathbf{C}] \mathrm{M}$} & {$[\mathbf{D}] \mathrm{M}$} & \% conversion \\
\hline 0 & 0.00386 & 0.00204 & 0.00305 & 34 \\
5 & 0.00377 & 0.00192 & 0.00326 & 36 \\
10 & 0.00370 & 0.00172 & 0.00353 & 39 \\
15 & 0.00336 & 0.00176 & 0.00383 & 42 \\
25 & 0.00307 & 0.00151 & 0.00438 & 48 \\
40 & 0.00261 & 0.00115 & 0.00519 & 57 \\
61 & 0.00195 & 0.000910 & 0.00610 & 68 \\
80 & 0.00154 & 0.000687 & 0.00673 & 75 \\
\hline
\end{tabular}

${ }^{a}$ Time after completion of thermal equilibration period. 
run 2

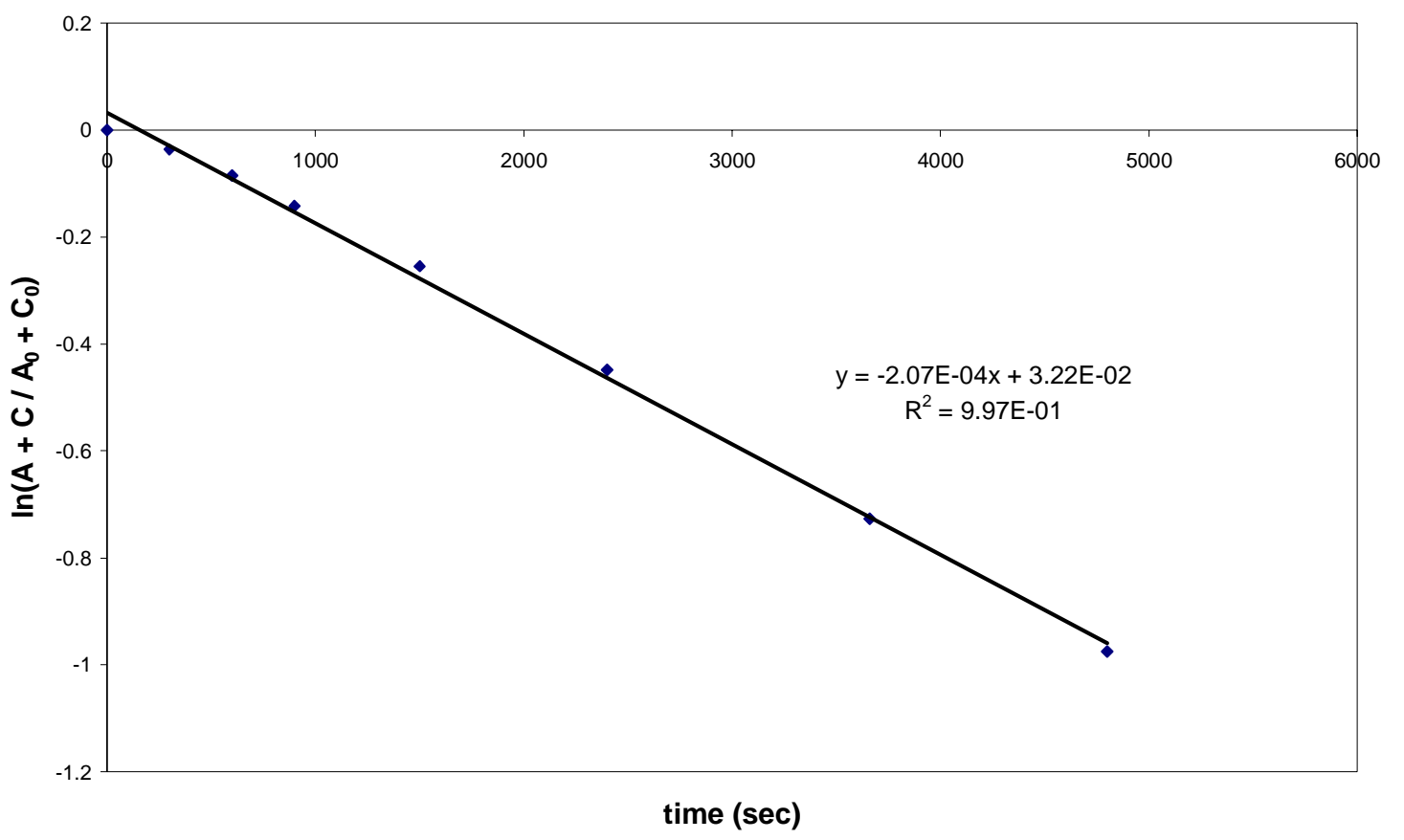

Figure S4. Plot of $\ln \left(\mathrm{R} / \mathrm{R}_{0}\right)$ vs time for run 2 . 


\section{Computational Details}

The computational methods used have been previously shown to accurately predict the structure of cationic zirconocene chlorocarbon adducts and cationic zirconocene species containing agostic interactions. ${ }^{\text {ii }}$ Stationary point DFT structures were optimized from the PM3 ${ }^{\text {iii }}$ level of theory with the BP86 functional ${ }^{\text {iv }}$ in Gaussian 03. ${ }^{\mathrm{v}}$ All main group atoms were modeled using the $6-31 \mathrm{G}^{*}$ basis set. ${ }^{\mathrm{vi}}$ Zirconium was modeled using the LANL2DZ basis set including an effective core potential. ${ }^{\text {vii }}$ Transition state structures were located using the QST3 method. ${ }^{\text {viii }}$ Frequency calculations were used to determine that there were no negative frequencies for the stationary point structures and one negative frequency for the TS structure corresponding to the reaction coordinate. Corrections to the Gibbs free energy were calculated at $188 \mathrm{~K}, 1 \mathrm{~atm}$ with a frequency scaling factor or 1 .

Structures of the van der Walls contact pairs $\mathbf{C} \cdot \mathrm{CD}_{2} \mathrm{Cl}_{2}$ and $\mathbf{A} \cdot(2$-butyne) were calculated using the methods described above. The difference between the energies of these species (with zero point energy correction at $188 \mathrm{~K}$ ) is a reasonable estimate of $\Delta G_{\text {eq }}(-1.69 \mathrm{kcal} / \mathrm{mol})$.

NBO analyses were performed using the NBO 5.0 program. ${ }^{\text {ix }}$ All figures were rendered using the MOLEKEL $4.3^{\mathrm{x}}$ software package. 


\section{Metrical parameters of the calculated structures of C, TS and D}

Table S1. Bond distances $(\AA)$ and angles (deg) in calculated structures of $\mathrm{Cp}_{2} \operatorname{Zr}(2-$ tol-4F-benzene)(2-butyne $)^{+}(\mathbf{C}), \mathrm{Cp}_{2} \mathrm{Zr}\left\{\mathrm{CMe}=\mathrm{CMe}\left(2-\mathrm{Me}-4-\mathrm{F}-\mathrm{C}_{6} \mathrm{H}_{3}\right)\right\}^{+}(\mathbf{D})$ and the transition state (TS) linking $\mathbf{C}$ and $\mathbf{D}$.

\begin{tabular}{lccc}
\hline & C & TS & D \\
\hline $\mathrm{Zr}-\mathrm{C}(\mathrm{B} 1)$ & 2.854 & 2.407 & 2.276 \\
$\mathrm{Zr}-\mathrm{C}(\mathrm{B} 2)$ & 2.853 & 2.778 & 3.040 \\
$\mathrm{Zr}-\mathrm{C}(\mathrm{Ar} 1)$ & 2.229 & 2.335 & 2.917 \\
$\mathrm{Zr}-\mathrm{H}(\operatorname{agostic})$ & 2.481 & 3.132 & 2.652 \\
$\mathrm{Zr}-\mathrm{C}(\mathrm{Ar} 6)$ & 2.700 & 3.159 & 2.559 \\
$\mathrm{C}(\mathrm{B} 1)-\mathrm{C}(\mathrm{B} 2)$ & 1.235 & 1.263 & 1.372 \\
$\mathrm{C}(\mathrm{B} 2)-\mathrm{C}(\mathrm{Ar} 1)$ & 4.030 & 2.562 & 1.495 \\
$\mathrm{Zr}-\mathrm{Cp}(1)$ & 2.237 & 2.261 & 2.238 \\
$\mathrm{Zr}-\mathrm{Cp}(2)$ & 2.252 & 2.269 & 2.240 \\
$\mathrm{C}(\mathrm{B} 1)-\mathrm{Me}(1)$ & 1.469 & 1.501 & 1.512 \\
$\mathrm{C}(\mathrm{B} 2)-\mathrm{Me}(2)$ & 1.470 & 1.466 & 1.523 \\
$\mathrm{Cp}(1)-\mathrm{Zr}-\mathrm{Cp}(2)$ & 129.5 & 125.8 & 130.0 \\
$\mathrm{Zr}-\mathrm{C}(\mathrm{B} 1)-\mathrm{C}(\mathrm{B} 2)$ & 77.5 & 93.1 & 110.4 \\
$\mathrm{Zr}-\mathrm{C}(\mathrm{B} 1)-\mathrm{Me}(1)$ & 116.1 & 124.4 & 127.7 \\
$\mathrm{C}(\mathrm{B} 1)-\mathrm{C}(\mathrm{B} 2)-\mathrm{Me}(2)$ & 167.0 & 161.0 & 125.2 \\
$\mathrm{Zr}-\mathrm{C}(\mathrm{Ar} 1)-\mathrm{C}(\operatorname{Ar} 6)$ & 93.2 & 111.6 & 61.3 \\
$\mathrm{C}(\mathrm{B} 1)-\mathrm{C}(\mathrm{B} 2)-\mathrm{C}(\mathrm{Ar} 1)$ & 108.0 & 108.1 & 115.5 \\
\hline
\end{tabular}

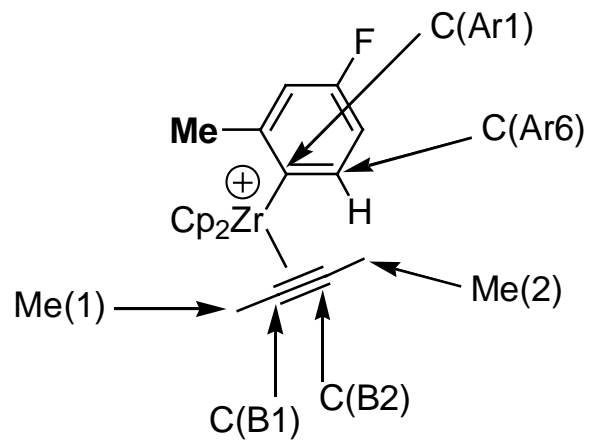




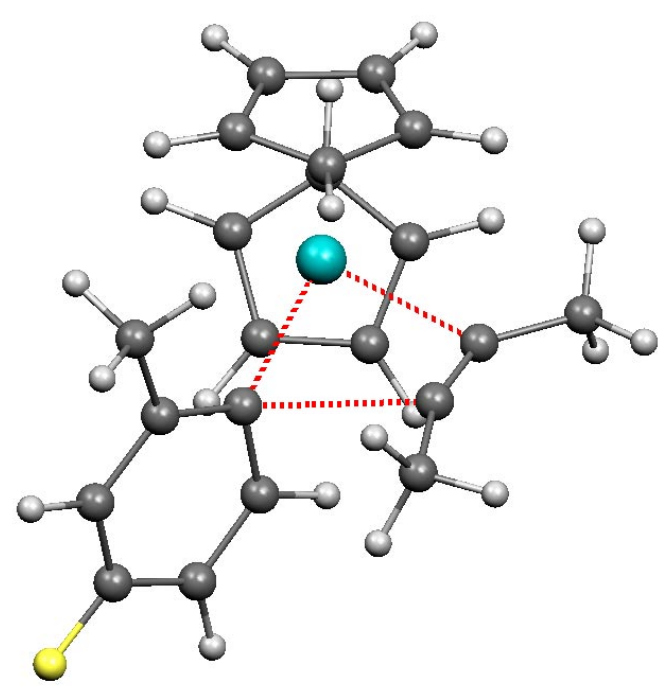

Figure S5. Transition state (TS) connecting $\mathbf{C}$ and $\mathbf{D}$.

i (a) Espenson, J. H. Chemical kinetics and reaction mechanisms; McGraw-Hill: New York, NY, 1981; pp 42-44. (b) Jordan, R. B. Reaction Mechanisms of inorganic and organometallic systems; Oxford University Press; New York, NY, 1991; pp 25-26.

ii Sydora, O. L.; Kilyanek, S. M.; Jordan, R. F. Organometallics 2007, 26, 4746.

iii (a) Stewart; J. J. P. J. Comp. Chem. 1989, 10, 209. (b) Stewart, J. J. P. J. Comp. Chem. 1989, 10, 221.

iv . (a) Becke, A. D. Phys. Rev. A 1988, 38, 3098. (b) Vosko, S. H.; Wilk, L.; Nusair, M. Can. J. Phys. 1980, 58, 1200. (c) Perdew, J. P. Phys. Rev. B 1986, 33, 8822.

${ }^{\mathrm{v}}$ Gaussian 03, Revision C.02, Frisch, M. J.; Trucks, G. W.; Schlegel, H. B.; Scuseria, G. E.; Robb, M. A.; Cheeseman, J. R.; Montgomery, Jr., J. A.; Vreven, T.; Kudin, K. N.; Burant, J. C.; Millam, J. M.; Iyengar, S. S.; Tomasi, J.; Barone, V.; Mennucci, B.; Cossi, M.; Scalmani, G.; Rega, N.; Petersson, G. A.; Nakatsuji, H.; Hada, M.; Ehara, M.; Toyota, K.; Fukuda, R.; Hasegawa, J.; Ishida, M.; Nakajima, T.; Honda, Y.; Kitao, O.; Nakai, H.; Klene, M.; Li, X.; Knox, J. E.; Hratchian, H. P.; Cross, J. B.; Bakken, V.; Adamo, C.; Jaramillo, J.; Gomperts, R.; Stratmann, R. E.; Yazyev, O.; Austin, A. J.; Cammi, R.; Pomelli, C.; Ochterski, J. W.; Ayala, P. Y.; Morokuma, K.; Voth, G. A.; Salvador, P.; Dannenberg, J. J.; Zakrzewski, V. G.; Dapprich, S.; Daniels, A. D.; Strain, M. C.; Farkas, O.; Malick, D. K.; Rabuck, A. D.; Raghavachari, K.; Foresman, J. B.; 
Ortiz, J. V.; Cui, Q.; Baboul, A. G.; Clifford, S.; Cioslowski, J.; Stefanov, B. B.; Liu, G.; Liashenko, A.; Piskorz, P.; Komaromi, I.; Martin, R. L.; Fox, D. J.; Keith, T.; Al-Laham, M. A.; Peng, C. Y.; Nanayakkara, A.; Challacombe, M.; Gill, P. M. W.; Johnson, B.; Chen, W.; Wong, M. W.; Gonzalez, C.; and Pople, J. A.; Gaussian, Inc., Wallingford CT, 2004.

${ }^{v i}$ (a) Rassolov, V. A.; Ratner, M. A.; Pople, J. A.; Redfern, P. C.; Curtiss, L. A. J. Comp. Chem. 2001, 22, 976. (b) Rassolov, V. A.; Pople, J. A.; Ratner, M. A.; Windus, T. L. J. Chem. Phys. 1998, 109, 1223. (c) Ditchfield, R.; Hehre, W.J.; Pople, J. A. J. Chem. Phys. 1971, 54, 724.

vii (a) Hay, P. J.; Wadt, W. R. J. Chem. Phys. 1985, 82, 270. (b) Wadt, W. R.; Hay, P. J. J. Chem. Phys. 1985, 82, 284. (c) Hay, P. J.; Wadt, W. R. J. Chem. Phys. 1985, 82, 299. viii (a) C. Peng, P. Y. Ayala, H. B. Schlegel, and M. J. Frisch, J. Comp. Chem. 17, 49 (1996). (b) C. Peng and H. B. Schlegel, Israel J. Chem . 33, 449 (1993).

${ }^{i x}$ NBO 5.0. E. D. Glendening, J. K. Badenhoop, A. E. Reed, J. E. Carpenter, J. A. Bohmann, C. M. Morales, and F. Weinhold (Theoretical Chemistry Institute, University of Wisconsin, Madison, WI, 2001); http://www.chem.wisc.edu/ nbo5 ${ }^{x}$ MOLEKEL 4.3, P. Flükiger, H.P. Lüthi, S. Portmann, J. Weber, Swiss Center for Scientific Computing, Manno (Switzerland), 2000-2002. Stefan Portmann \& Hans Peter Lüthi. MOLEKEL: An Interactive Molecular Graphics Tool. CHIMIA, 2000, 54,766-770. 